\title{
Yeraltı suyunda alg kültürleri ile nitrat kirliliğinin giderimi
}

\section{Removal of nitrate from groundwater by using algae culture}

\author{
Eda Tuna Öztürk* (D) S Serdar Göncü \\ Anadolu Üniversitesi, Mühendislik Fakültesi, Çevre Mühendisliği Bölümü, Eskişehir, 26555, Türkiye \\ ${ }^{*}$ Corresponding author: edatuna@anadolu.edu.tr
}

\section{How to cite this paper:}

Tuna Öztürk, E. \& Göncü, S. (2017). Removal of nitrate from groundwater by using algae culture. Ege Journal of Fisheries and Aquatic Sciences, 34(4):463-467. doi: 10.12714/egejfas.2017.34.4.15

\begin{abstract}
Öz: İçme suyu kaynağı olarak kullanılan yeraltı suları diğer su kaynaklarına göre daha güvenilir ve temiz olmasına karşın, kirlenmesi durumunda arıtılması oldukça güçtür. Yeraltı suyunun önemli kirlilik parametrelerinden biri olan nitrat, yeraltı suyuna evsel ve endüstriyel atıklar, tarımsal faaliyetler, gübreler ve hayvan atıkları ile ulaşmaktadır. Nitrat kirliliğinin gideriminde denitrifikasyon, iyon değiştirme, ters ozmoz gibi yöntemler kullanılsa da biyolojik arıtma yöntemleri etkin şekilde kullanılmaya devam etmektedir. Yeraltı sularından nitrat kirliliğinin gideriminde biyolojik yöntemler arasında mikroalgler alternatif bir yöntem olarak kullanılmaktadır. Buna karşın, yeraltı sularının kimyasal bileşimi ve mikroalglerin büyütülmesi ile ilgili araştıııması gereken birçok konu bulunmaktadır
\end{abstract}

Anahtar kelimeler: Mikroalg, nitrat giderimi, yeraltı suyu, biyolojik arıtım

Abstract: Although groundwater is more reliable and clean water resource when it is used as a drinking water, it is difficult to treat once it is polluted. One of the most important pollution paremeters in groundwater is nitrate which might be discharged by domestic or industrial wastes, agricultural activities, fertilizers and animal wastes. Even though denitrification, ion exchange, reverse osmos are widely used treatment methods for nitrate removal, biological treatment methods have effectively been also used. Nitrate removal from groundwater by microalgae is used as an alternative method in biological treatment methods. On the other hand, there are some topics which need to be investigated about chemical compositon of groundwater and microalgae growth.

Keywords: Microalgae, nitrate removal, groundwater, biological treatment

\section{Gíriş}

Dünya'daki toplam su miktarı 1,4 milyar $\mathrm{km}^{3}$ olup, okyanus ve denizlerde tuzlu su olarak bulunan kısım bu miktarın $\% 97,5^{\prime}$ ini, nehir ve göllerde tatlı su olarak bulunan kısım ise $\% 2,5$ 'ini oluşturmaktadır. Miktarı az olan tatlı su kaynaklarının \%90'ının kutuplarda ve yeraltı sularında bulunmasından dolayı insanların kolaylıkla erişebileceği su miktarı oldukça kısıtıdır (Anonim, 2014).

Devlet Su Işleri Genel Müdürlüğü'nden (DSi) alınan verilere göre, Türkiye'nin yıllık yüzeysel su potansiyeli yaklaşık olarak 193 milyar $\mathrm{m}^{3}$ tür. Yüzeysel su kaynaklarına ek olarak, Türkiye'nin yıllık toplam yeraltı su kaynakları yaklaşık olarak 14 milyar $\mathrm{m}^{3}$ ve toplam kullanılabilir yüzeysel ve yeraltı su kaynakları 112 milyar $\mathrm{m}^{3}$ civarındadır (Anonim, 2014).

Yüzeysel su kaynaklarının azalmaya başlaması ile yeraltı suları içme suyu kaynağı olarak kullanılmaya başlanmaktadır. Yeraltı suyu diğer su kaynaklarına göre göreceli olarak daha güvenilir ve temiz olmasından dolayı uzun yıllardır içme suyu kaynağı olarak kullanılmaktadır. Zaman içerisinde aşırı kullanımından dolayı yeraltı sularına organik ve inorganik kirlilik girişi olmuş ve suyun kalitesi düşmüştür (Majumdar, 2000).
İnorganik kirleticilerden birisi olan nitrat kirliliğinin başlıca kaynakları atıksular, gübreler ve hayvan atıklarıdır. Azot içeriği çok fazla olan gübrelerin tarımda gereğinden fazla kullanılması yeraltı sularındaki yüksek nitrat derişiminin başlıca sebeplerinden birisidir (Hu vd., 2000). Nitratın dışında, amonyum ve amit formunda bulunan azot, mineralleşme vasıtasıyla toprakta nitrat oluşumuna sebep olmakta ve bu oluşum tropik ve subtropikal topraklarda daha hızlı olmaktadır. Sudaki çözünürlüğünün fazla ve toprak partikülleri tarafından kısa süreli adsorpsiyonundan dolayı, nitrat eğer bitkiler tarafından emilmez ya da $\mathrm{N}_{2} \mathrm{O}$ ve $\mathrm{N}_{2}$ 'ye denitrifiye olmaz ise vadoz bölgeye ve özellikle yeraltı sularının bulunduğu akifere infiltre olmaktadır. İnfiltre olan kısım toprağın özellikleri ve toprak sisteminde bulunan su miktarı ile kontrol edilmektedir (Majumdar, 2000). İdeal koşulların sağlanması durumunda bile tarımsal faaliyetlerde kullanılan azotlu gübrelerin sadece $\% 50$ 'si bitkiler tarafından kullanılmakta, \%2-20'si denitrifikasyon nedeniyle kaybedilmekte, \%15-25'i killi toprakta bulunan organik bileşikler ile birleşmekte ve geriye kalan \%210 'luk kısmı ise yeraltı ve yüzey sularına karışmaktadır (Sönmez, 2008). 
Nitratın doygun olmayan bölgeden infiltrasyonu arazi kullanım yöntemleri, arazi üzerindeki azot yükü türü, yeraltı suyu yenilenme miktarı, toprağın azot dinamiği, toprak karakteristiği ve su tablasının zamansal olarak değişiklik göstermesi gibi birçok faktörün birbiriyle etkileşimi sonucunda gerçekleşmektedir (Şekil 1).

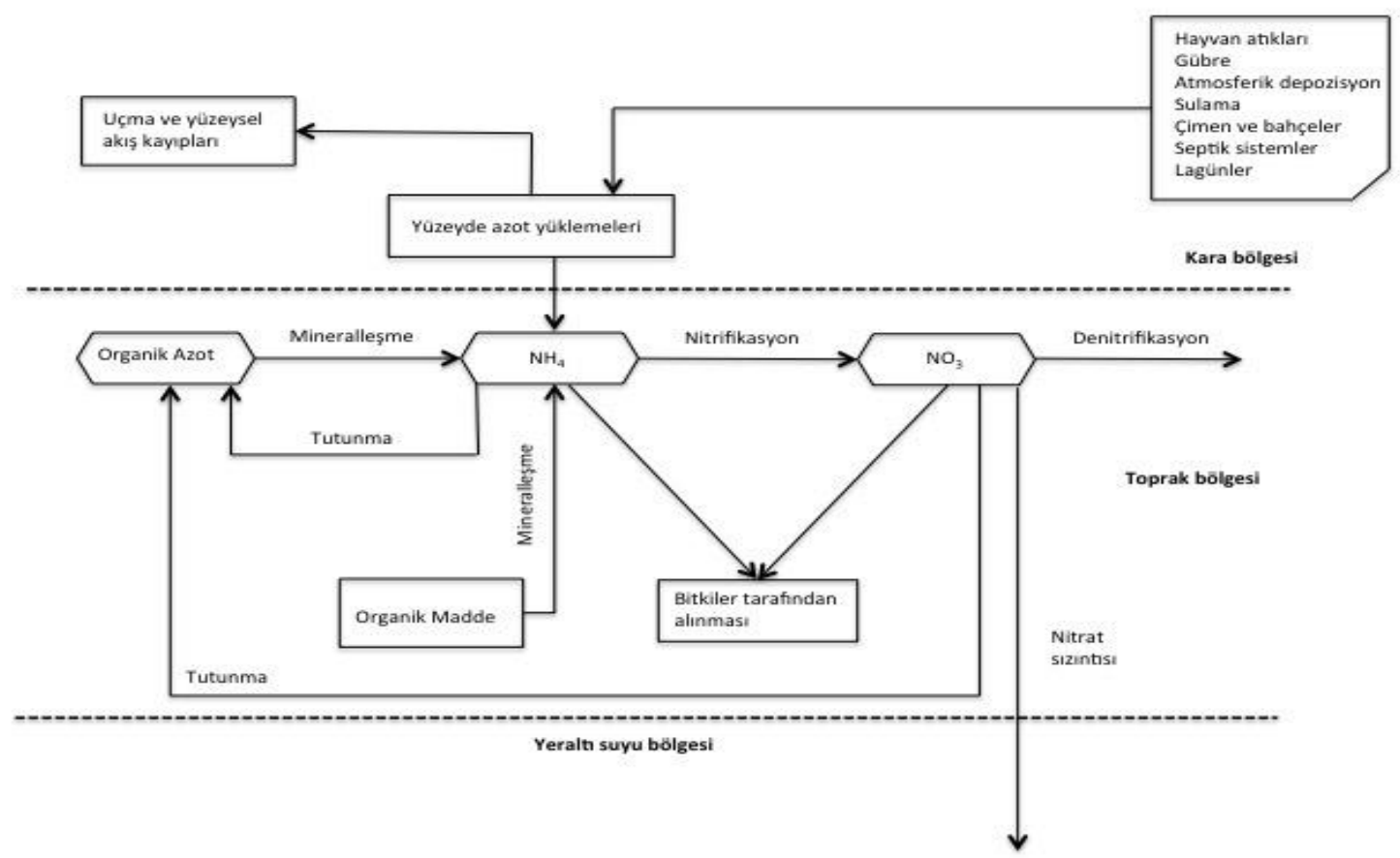

Şekil 1. Nitratın yeraltı suyuna geçişi sırasında gerçekleşen sürecin şematik gösterimi (Almasri, 2007)

Figure 1. A shematic representation of the processes during difussion of nitrate through groundwater (Almasri, 2007)

Nitrat yeraltı suyuna ulaştığında, adveksiyon ve dispersiyon gibi etkenlerle akiferde taşınmaktadır. Uygun koşulların olması durumunda nitrat denitrifikasyon sürecine maruz kalmaktadır (Frind, 1990; Korom, 1992; Postma vd., 1991; Shamrukh vd., 2001; Tesoriero vd., 2000; Tesoriero ve Voss, 1997)

Yeraltı sularında nitrat kirliliği küresel bir artış göstermektedir. Birçok ülkede içme suyu kaynaklarındaki nitrat miktarlarının sürekli olarak arttığı görülmektedir. Türk İçme Suyu Standardı TS 266'da nitrat derişimi için sınır değer 50 mg $\mathrm{NO}_{3} / \mathrm{L}$ olarak belirlenmiştir (Anonim, 2005; Polat, 2007). Amerika Birleşik Devletleri'nde Çevre Koruma Ajansı (EPA) tarafından içme sularında nitrat limit değeri ise $45 \mathrm{mg} \mathrm{NO}_{3} / \mathrm{L}$ 'dir (Hu vd., 2000). Yeraltı suları birçok bölgede içme suyu olarak kullanılmakta ve yüksek nitrat derişiminden dolayı halk sağlığına, özellikle de yeni doğan bebeklerde ciddi sağlık sorunlarına neden olmaktadır. Yetişkinler için yüksek nitrat derişimleri mide kanserine neden olurken, yeni doğan bebeklerde nitrat nitrite indirgenmekte ve kandaki hemoglobin demirini oksitleyerek oksijen taşınamaması sonucunda mavi bebek sendromuna (methemoglobinemi) neden olmaktadır (Almasri, 2007; Kapoor ve Viraraghavan, 1997).
EPA 1990 yılında yayınladığı raporda 250.000 su kaynağındaki nitrat değerinin maksimum kirlilik seviyesinde olduğunu açıklamıştır. Dünya Sağlık Örgütü (WHO), 2004 yılında dünya genelinde 2000 kaynakta yaptığı çalışmada ise, kaynakların \%30'unun 24 mg/L'den daha fazla nitrat derişimine sahip olduğunu belirtmiştir (Archna vd., 2012).

Türkiye'de yeraltı suyunda nitrat kirliliği ile ilgili yapılan çalışmaların büyük bir bölümünde nitrat derişiminin sınır değerlerin üzerinde olduğu görülmüştür. Ege Bölgesi'nde Urla ve Menemen civarında yapılan çalışmada, 14 farklı kuyudan alınan örneklerde yeraltı suyu kirliliğinin tarımsal faaliyetlerde gübre ve tarım ilacı kullanımından dolayı arttığı gözlenmiştir. Menemen'de yapılan ölçümlerde iki kuyudaki nitrat derişimlerinin $53 \mathrm{mg} / \mathrm{L}$ ve $146 \mathrm{mg} / \mathrm{L}$ olduğu belirlenmiştir. Urla bölgesinde ise altı farklı kuyu incelenmiş ve nitrat değerlerinin 69 ve 129 mg/L arasında değiştiği görülmüştür (Aslan, 2001).

Konya'da yapılan çalışmada, şehrin yaklaşık olarak \%75'ine su kaynağı olan yeraltı sularında nitrat kirliliği analiz edilmiştir. 1998 yılında 139 kuyuda nitrat ölçümü ile başlanılan çalışma 2001 yılında 156 kuyuda gerçekleştirilmiştir. Ortalama 
nitrat derişimi 1998 yılında 2,2 mg/L iken 2001 yılında 16,1 mg/L'ye çıktığı, şehir merkezine doğru arttığı görülmüştür (Nas ve Berktay, 2006).

2007 yılında Çakmak tarafından yapılan tez çalışmasında, Ekim 2005-Temmuz 2006 tarihleri arasında Eskişehir ilinde yeraltı ve yüzeysel sularda bulunan nitrat kirlilikleri incelenmiştir. 15 farklı yeraltı suyu örnekleme noktasında yapılan nitrat ölçümlerinde nitrat değerlerinin $13-360 \mathrm{mg} / \mathrm{L}$ arasında değiştiği görülmüştür. 8 adet örnekleme noktasında ise nitrat derişimi değerlerinin Dünya Sağlık Örgütü (WHO) tarafından belirlenen sınır değer olan 50 mg/L'yi aştığı görülmüştür (Çakmak, 2007).

Ağustos, 2008 yılında Deliçay ve Tarsus Çayı arasında kalan kıyı akiferinde yapılan arazi çalışması sonucunda toplamda 205 kuyudan yeraltı suyu örnekleri alınmış ve suyun içerisindeki nitrat derişimleri analiz edilmiş̧ir. Elde edilen sonuçlarda nitrat derişiminin çalışma alanında incelenen kuyularda 0,44-73,48 $\mathrm{mg} / \mathrm{L}$ arasında olduğu bulunmuştur. Nitrat derişiminin yüksek olduğu bölgeler incelendiğinde, yeraltı suyuna nitrat girişinin 0 alanda bulunan çeşitli sanayi faaliyetlerinden ve evsel atıklardan kaynaklandığ düşünülmektedir (Korkut, 2009).

Uğurluoğlu (2013) tarafından Mart 2012 - Şubat 2013 tarihleri arasında Eskişehir yakınlarında bulunan Seydişehir Havzası'nda yapılan çalışmada, 20 farklı kuyudan yeralıı suyu örnekleri alınarak sıcaklık $\left({ }^{\circ} \mathrm{C}\right)$, iletkenlik $(\mu \mathrm{S} / \mathrm{cm})$, tuzluluk (ppt), toplam çözünmüs, katı (g/L), pH, ORP (mV), amonyum (mg/L-N), nitrat (mg/L-N), çözünmüss, oksijen ( $\mathrm{mg} / \mathrm{l})$, nitrit $(\mathrm{mg} / \mathrm{L})$ ve sülfat $(\mathrm{mg} / \mathrm{L})$ ölçümleri yapıımışıı. İçme suyu amacı ile kullanılan Hamidiye Köyü'nde bulunan kuyuda yapılan ölçümlerde yaz mevsiminde nitrat derişiminin $70 \mathrm{mg} / \mathrm{L}$, kış mevsiminde ise $72 \mathrm{mg} / \mathrm{L}$ olduğu gözlemlenmiştir. Seyitgazi ilçesinde bulunan kuyuda yapılan ölçümlerde ise nitrat derişiminin sonbahar mevsiminde $37 \mathrm{mg} / \mathrm{L}$, kış mevsiminde ise 56 mg/L olduğu görülmüştür.

\section{Nitrat Kirliliği Giderim Yöntemleri}

Yeraltı sularından nitrat kirliliğinin giderimi fiziksel, kimyasal ve biyolojik teknolojiler kullanılarak yapılabilmektedir. Fiziksel ve kimyasal metotlar kullanılan arıtım yöntemleri, dışarıdan bir enerji kaynağına (elektrik veya organik karbon) ve/veya kimyasal madde eklemesine gereksinim duyduğundan üretilen atığın bertaraf edilmesi gerekmektedir. Bu yüzden bu metotları kullanmak problemli ve pahalı olabilmektedir (Hu vd., 2000). Fizikokimyasal yöntemlerden olan ters ozmoz ve iyon değiştirme teknikleri tam ölçekli uygulamalarda denenmiş olsa da, nitrat gideriminde düşük seçicilik göstermekte ve yoğun miktarda bertaraf edilmeyi gerektiren bir atık açı̆̆a çıkmaktadır. Biyolojik denitrifikasyon - atık üretmeden bakteriler tarafından nitratın azot gazına indirgenmesi- en çok çalışılan metot olup genellikle yeraltı sularından nitrat gideriminin ticari amaçla yapıldığı yerlerde kullanılmaktadır. Her ne kadar ikincil arıtıma intiyaç duyulsa da, biyolojik denitrifikasyon yöntemi için uygun bir monitorlama ve kontrol gereklidir. Bahsedilen bu yöntemler nitrat kirliliği giderimini pahalı hale getirdiğinden, uygun ve daha kolay bir işletime sahip olan yöntemlere ihtiyaç duyulmuştur (Lin vd., 2002).

Yeraltı sularından nitrat kirliliğinin giderilmesinde kullanılabilecek bir diğer yöntem ise fotosentetik mikroorganizmalardır. Fotosentetik mikroorganizmalar, siyanobakter gibi, nitrat giderimi için bağlı azot, inorganik karbon ve büyümek için ışığa intiyaç duymaktadır. Mikroalg kültürleri ışıktan yararlanarak fotosentez ile nitratı protein gibi azot içeren organik bileşenlere dönüştürürler $(\mathrm{Hu}$ ve Sommerfeld, 2004). İ̧me suyu kaynaklarında nitrat kirliliğinin fotosentetik sistemler ile giderilmesi yeni bir araştırma konusu olduğundan kaynaklar çok sınırıdır. Mikroalgler ile atıksu arıımı çalışmaları kırk yıldan fazla süredir atıksu kaynaklarından besin ve ağır metal gideriminde alternatif bir yöntem olarak kullanılmak için incelenmektedir (Hoffman, 1998; Lee ve Lee, 2002). Her ne kadar araştırmaların bir kısmı içme sularının arıtılmasında bu tekniğin kullanılabileceğini belirtse de, yeralıı sularının kimyasal bileşimi ( $\mathrm{pH}$, çözünmüş inorganik karbon, besin değeri ve metaller), yeraltı sularını atıksulardan farklı kılmaktadır (Hu vd., 2000).

Biyolojik metotlar kullanılarak nitrat kirliliğinin giderimine yönelik çalışmalar incelendiğinde, bu yöntemin daha çok atıksulardan nitrat gideriminde kullanıldığı görülmüştür. Düşük karbon/azot $(\mathrm{C} / \mathrm{N})$ oranında, atıksudan mikroalgler ile azot gideriminin mümkün olup olmadığı test edilmiştir. Nitratın azot kaynağı olarak kullanıldığı iki farkı yapay atıksu içerisine Chlorella kessleri kültürü ekilmiştir. Atıksulardan bir tanesi organik karbon kaynağı olarak glukoz içerirken diğerinde organik karbon kaynağı bulunmamaktadır. Havalandırma hızı 1 vvm'nin üzerinde iki her iki atıksudaki büyüme hızının aynı olduğu görülmüştür. Bu sonuçlar karbondioksitin sınırlayıcı olmadığı durumlarda mikroalglerin atıksulardan nitrat gideriminde kullanılabileceğini göstermiştir. Organik karbon içermeyen atıksu da dahil olmak üzere, nitrat derişimi başlangıç̧a $140 \mathrm{mg} \mathrm{NO} 3^{-} \mathrm{N} / \mathrm{mL}$ iken, 10 gün sonunda $2 \mathrm{mg}$ $\mathrm{NO}_{3}-\mathrm{N} / \mathrm{mL}$ 'ye düşmüştür (Lee ve Lee, 2002).

Upadhyaya vd. (2010) yllında seri olarak yerleştirimiş iki adet biyolojik aktif karbon (BAC) reaktöründen oluşan sistemde sentetik yeraltı suyundan nitrat ve arsenik giderimi denenmişstir. BAC reaktörün içerisinde bulunan karışık mikrobiyolojik biyofilm çözünmüş oksijen, nitrat, arsenik ve sülfatı elektron alıcı olarak kullanmıştır. Girişteki nitrat derişimi $50 \mathrm{mg} / \mathrm{L}$ iken, bu yöntem ile nitrat derişimi $0,2 \mathrm{mg} / \mathrm{L}$ 'ye düşürülmüştür. $\mathrm{Bu}$ çalışma ile ilk kez biyoreaktör kullanılarak içme suyu kaynaklarından nitrat ve arsenik gideriminin yapılabildiğini göstermiştir.

\section{Alg Üretim Sistemleri}

Mikroalgler açık havuz sistemleri ve kapalı fotobiyoreaktör sistemler olmak üzere iki farklı şekilde büyüyebilirler. Her iki sistemin de avantajları ve dezavantajları bulunmaktadır. Açık havuz sistemleri daha düşük enerji ihtiyacına sahip olup, büyük ölçekli alg biyokütlesi üretimleri için daha ucuzken, kapalı sistemlerin birçoğu yapay ışık altında gerçekleştirildiğinden enerji maliyeti oldukça yüksektir. Bunun yanı sıra, açık havuz 
sistemlerinde güneş ışığından faydalanılsa da yalnızca alg kültürlerinin küçük bir kısmı başarılı olarak büyüyebilmektedir. Kapalı sistemlerde ise büyüme koşulları daha düzenli takip edildiğinden alg üretimi daha fazladır. Açık havuz sistemlerindeki problemler genellikle teorik olarak hesaplanandan daha düşük üretimin gerçekleşmesi ve çevresel koşulların kontrolünün daha zor olmasıdır. Buharlaşma kayıpları, besi yerindeki sıcaklık dalgalanmaları, $\mathrm{CO}_{2}$ 'in yetersiz olması, yetersiz karıştırma ve ışığın limitl olması alg kültürlerinin büyümesini engelleyen çevresel koşulların başında gelmektedir. (Borowitzka, 1999; Brennan ve Owende, 2010).

Mikroalgler üç farklı kaynaktan $\mathrm{CO}_{2}$ 'i bağlayabilirler; bunlar sırası ile atmosferdeki $\mathrm{CO}_{2}$, ağır sanayi endüstrisinden atılan gazların içinde bulunan $\mathrm{CO}_{2}$ ve çözünür karbonatlardan gelen $\mathrm{CO}_{2}$ 'dir. Doğal büyüme koşulları altında, mikroalgler havadaki $\mathrm{CO}_{2}$ 'i asimile ederler. Mikroalglerin birçoğu tipik olarak 150,000 ppmv'ye kadar yüksek $\mathrm{CO}_{2}$ seviyelerini kullanabilirler. $\mathrm{Bu}$ nedenle, ortak üretim ünitelerinde, $\mathrm{CO}_{2}$ alg besi yerine ya enerji santralleri gibi dış kaynaklardan ya da $\mathrm{Na}_{2} \mathrm{CO}_{3}$ ve $\mathrm{NaHCO}_{3}$ gibi çözünebilir karbonat şeklinde beslenebilir. Ancak, yoğun karbondioksit içeriğine sahip olan baca gazı gibi kaynaklar ile atık besin maddelerinin bir araya getirilmesi uygun maliyetli alg üretimi için başlıca zorluklardan birisidir. (Brennan ve Owende, 2010; Christenson ve Sims, 2011).

\section{Alg Biyokütlesinin Ayrılması ve Hasat Edilmesi İçin Kullanılan Yöntemler}

Arıtım gerçekleştikten sonra mikroalglerin ortamdan uzaklaştırıması gerekmektedir. Bunun için uygulanabilecek yöntemler; yerçekimi ile çöktürme, flokülasyon, santrifüjleme, ve filtrasyondur. Alg biyokütlesinin hasat edilmesinde sırası ile flokülasyon ve yerçekimi ile çöktürme işleminin uygulanması en yaygın kullanılan tekniklerden birisidir. Flokülasyon ile oluşturulan alg floklarının yerçekimi ile çöktürülmesi bu sürecin verimliliğini arttırmaktadır. Sürekli alg hasatının yapılması durumunda, çok küçük boyutlu mikroalgler için yerçekimi çökelme hızı oldukça düşük olmakla birlikte, alg biyokütlesini uzun süre karanlık ve statik koşullar altında tutmak solunum ve bakteriyolojik bozunmadan dolayı biyokütlede önemli oranda bir azalmaya sebep olmaktadır. Santrifüjleme işlemi neredeyse her tür mikroalge uygulanmaktadır. Santrifüj işleminde çöktürme işlemi ile aynı prensip uygulanmaktadır ancak yerçekimi kuvvetinin fazla olması çökme hızını artırmaktadır. Partikül boyutu ve yoğunluk farkı santrifüj ile ayırma işlemindeki başlıca faktörlerdir. Filtrasyon işlemi hasat yöntemleri arasında en rekabetçi olandır. Genellikle boyutları $70 \mu$ m'den büyük olan algler için kullanılmaktadır. Filtrasyon verimliliğini artırmak için diatomlu topraklar ya da selüloz kullanılmaktadır. Bununla birlikte basınç ya da emme altında çalışan konvansiyonel filtrasyon Chlorella, Dunaliella ve Scenedesmus gibi küçük boyutlu algleri için uygun değildir. (Rathod, 2014; Singh vd., 2013).

\section{Yeraltı Suyundan Nitrat Kirliliğinin Alg Biyokütlesi ile Giderimi Üzerine Yapılan Çalışmalar}

Yeraltı suyundan nitrat kirliliğinin alg biyokütlesi ile arıtılması konusunda literatürde sınırlı sayıda bulunan çalışmalardan bir tanesi Hu ve arkadaşları tarafından 2000 yılında yapılan çalışmadır. Bu çalışmada üç farklı siyanobakter türü kullanılarak, yeraltı suyundan nitrat kirliliği giderimine olan etkileri incelenmiştir. Nitrat ile kirlenmiş yeraltı suyuna fosfor ve bazı iz elementlerin ilave edilmesi ile alg kültürlerinin büyümesi için gerekli besi yeri sağlanmıştır. Synechococcus sp. PCC 7942 türünün en yüksek nitrat giderim hızına sahip olduğu gözlenmiştir. Işık şiddetinin kademeli olarak 100 umol foton m$2 \mathrm{~s}^{-1}$ çıkartılması ile nitrat giderim hızı da artış göstermiştir. İki günlük kültür periyodunda, $730 \mathrm{~nm}$ optik yoğunlukta ortalama nitrat giderim hızı $0.05 \mathrm{mM} \mathrm{NO}_{3}$ s $^{-1}$ olarak bulunmuştur (Hu vd., 2000).

Hu ve Sommerfeld tarafından Arizona'da 2004 yılında yapılan çalışmada beş farklı alg kültürü izolasyonu yapılarak, alg kültürlerinin yeraltı suyundan nitrat kirliliği giderimi üzerine olan etkileri incelenmiştir. Tüm kültürler $300 \mathrm{~mL}$ cam kolon reaktörlerde $25{ }^{\circ} \mathrm{C}$ ve $185 \mu \mathrm{mol} \mathrm{m} \mathrm{m}^{-2} \mathrm{~s}^{-1}$ ışık altında büyütülmüştür. BG-11 media maksimum alg büyümesini gözlemlemek için kontrol amacıyla kullanılmıştır. Safsızlaştırılan kültürlerden Chlorella sp. 'in yeraltı suyuna kıyasla BG-11 media içerisinde daha hızıı büyüdüğü ve nitratı daha hızlı giderdiği gözlenmiştir. BG-11 media içerisinde bulunan $50 \mathrm{mg} / \mathrm{L} \mathrm{NO}_{3}-\mathrm{N}$ derişimi Chlorella sp. tarafından 24 saat içerisinde $10 \mathrm{mg} / \mathrm{L} \mathrm{NO}_{3}-\mathrm{N}$ 'ye kadar giderilirken, aynı giderim işlemi yeraltı suyunda 36 saatte gerçekleşmiştir. Chlorococcum sp. ve Scenedesmus sp. ile yapılan aynı deneyde, her iki kültürün de BG-11 media ve yeraltı suyundaki büyüme potansiyellerinin benzer olduğu görülmüştür. $50 \mathrm{mg} / \mathrm{L}$ $\mathrm{NO}_{3}-\mathrm{N}$ derişimine sahip olan $\mathrm{BG}-11$ media ve yeraltı suyundaki nitrat azotu Chlorococcum sp. ile 32 saat içerisinde, Scenedesmus sp. ile 24 saatten daha kısa bir sürede tamamen giderilmiştir. Ulothrix sp. ve Pseudanabaena sp.'in ise yüzeysel su ve BG-11 media içinde benzer büyüme ve giderim potansiyeli gösterdiği gözlenmiştir. Ancak diğer kültürlere kıyasla nitrat giderimine olan etkileri oldukça yavaştır. Ulothrix sp. 48 saatlik zaman periyodunun sonunda Ulothrix sp. tarafından $50 \mathrm{mg} / \mathrm{L} \mathrm{NO}_{3}-\mathrm{N}$ derişiminin yalnızca \%50'sinin arıtıldığı görülmüştür. Pseudanabaena sp. kullanılması durumunda ise Ulothrix sp.'den daha iyi performans göstermesine karşın istenilen verim elde edilememiştir (Hu ve Sommerfeld, 2004).

\section{SONUÇ}

Nitrat kirliliği giderim yöntemleri kıyaslandığında, alg kültürü ile giderim çalışmalarının atıksularda çok sıklıkla görüldüğü ancak yeraltı suyu kirliliği çalışmalarında yeni yeni kullanılmaya başlandığı görülmüştür. Nitrat kirliliğinin gideriminde kullanılan yöntemler incelendiğinde alg biyokütlesinin kullanılmasının temel avantajlarının olduğu görülmektedir. Alg kültürlerinin nitrat giderimi yaparken aynı zamanda karbondioksiti gideriyor olması, güneş ışığı haricinde ilave bir enerji gereksinimine 
intiyaç duymaması ve kimyasal maddeye intiyacının diğer yöntemlere göre çok daha az olması başıca avantajlarıdır.

Ancak bunun yanında yeraltı suyu sıcaklığının ortalama 12 ${ }^{\circ} \mathrm{C}$ olması, birçok alg kültürünün büyümesi için uygun bir sıcaklık değeri değildir. Bu nedenle alg kültürü ile yeraltı suyunda nitrat kirliliği gideriminin yapılabilmesi için ex-situ arıtım yöntemleri kullanılarak yeraltı suyu, kaynağından çıkartılarak arııımı yapıımalıdır. Ayrıca alg kültürünün büyümesi için gerekli önemli bileşenlerden birisi olan fosfor, yeralt suyuna doğal ya da endüstriyel kaynaklardan ilave edilerek, alg biyokütlesinin nitrat kirliliğinin gideriminde biyoremediasyon uygulaması olarak kullanılması mümkün görünmektedir. Bu yöntemler ile yeraltı suyu sıcaklığının sınırlayıcı etkisi bertaraf edilerek uygun sıcaklıklara ulaşılabilir ve alglerin uygun koşullarda arıtma sürecini gerçekleştirmesi sağlanabilir.

Bu şartların sağlanabilmesi için yeraltı suyu pompaj debisine bağlı reaktör tasarımı, suyun istenilen sıcaklığa getirilmesi için gerekli ısı eşanjörlerinin tasarlanması, gerekli ışık şiddeti ve süresine göre yeterli ışığı alglere ulaştıracak bir reaktör tasarımının yapııması ve oluşan alg biyokütlesinin hasat edilerek arıtımı yapılan yeraltı suyunun tekrar yeraltına enjeksiyonunun sağlanması gibi süreçlerin planlanması gerekmektedir.

\section{KAYNAKÇA}

Almasri, M.N. (2007). Nitrate contamination of groundwater: A conceptual management framework. Environmental Impact Assessment Review 27(3):220-242. doi:10.1016/J.Eiar.2006.11.002

Anonim. (2005). İnsani Tüketim Amaçlı Sular Hakkında Yönetmelik. Alıntılama adresi: http://www.resmigazete.gov.tr/eskiler/2005/02/20050217-3.htm (17.02.2005).

Anonim. (2014). Devlet Su İşleri Genel Müdürlüğü Toprak Su Kaynakları. Alıntılama adresi: http://www.dsi.gov.tr/toprak-ve-su-kaynaklari (2014).

Archna, Sharma, S.K. \& Sobti, R.C. (2012). Nitrate removal from ground water: A review. E-Journal of Chemistry 9(4):1667-1675.

Aslan, S.T., A., Ovez, B., Yuksel, M. \& Alyanak, I. (2001). Investigating groundwater pollution around Urla and Menemen in the Aegean Region. Groundwaters and Environment Symposium (2001), Izmir, Turkey.

Borowitzka, M. (1999). Commercial production of microalgae: ponds, tanks, tubes and fermenters. Journald of Biotechnology 70:313-321.

Brennan, L. \& Owende, P. (2010). Biofuels from microalgae- A review of technologies for production, processing, and extractions of biofuels and co-products. Renewable and Sustainable Energy Reviews, 14:557-577.

Christenson, L. \& Sims, R. (2011). Production and harvesting of microalgae for wastewater treatment, biofuels, and bioproducts. Biotechnology Advances 29:686-702

Çakmak, Ö. (2007). Eskişehir ilinde yeraltı ve yüzeysel sulardaki nitrat kirliliğinin kirletici kaynakları göz önünde bulundurarak değerlendirilmesi. (Yüksek Lisans Tezi), Ondokuz Mayıs Üniversitesi.

Frind, E.D.W. Strebel, O. \& Boettcher, J. (1990). Modeling of multicomponent transport with microbial transformation in ground water: the Fuhrberg case. Water Resources Research 26(8):1707-1719.

Hoffman, J.P. (1998). Wastewater treatment with suspended and nonsuspended algae. Journal of Phycology 34:757-763.

Hu, Q. \& Sommerfeld, M. (2004). Selection of high performance microalgae for bioremediation of nitrate-contaminated groundwater. Alıntılama adresi: https://water.usgs.gov/wrri/grantetails.php?ProjectlD=2003AZ15B\&Year= 2003 (2003).

Hu, Q., Westerhoff, P. \& Vermaas, W. (2000). Removal of nitrate from groundwater by cyanobacteria: Quantitative assessment of factors influencing nitrate uptake. Applied and Environmental Microbiology 66(1):133-139

Kapoor, A. \& Viraraghavan, T. (1997). Nitrate removal from drinking water Review. Journal of Environmental Engineering-Asce 123(4):371-380. doi:10.1061/(Asce)0733-9372(1997)123:4(371)

Korkut, R.N. (2009). Deliçay-Tarsus Çayı (Mersin) arasındaki bölgedeki yeraltısularında nitrat ve nitrit kirliliğinin araştırılması. (Yüksek Lisans Tezi), Mersin Üniversitesi, Fen Bilimleri Enstitüsü.

Korom, S.F. (1992). Natural denitrification in the saturated zone - A review. Water Resources Research 28(6):1657-1668. doi:10.1029/92wr00252

Lee, K. \& Lee, C.G. (2002). Nitrogen removal from wastewaters by microalgae without consuming organic carbon sources. Journal of Microbiology and Biotechnology 12(6):979-985.

Lin, Y.F., Jing, S.R., Wang, T.W. \& Lee, D.Y. (2002). Effects of macrophytes and external carbon sources on nitrate removal from groundwater in constructed wetlands. Environmental Pollution 119(3):413-420. doi:10.1016/S0269-7491(01)00299-8

Majumdar, D.G.N. (2000). Nitrate pollution of groundwater and associated human health disorders. Indian Journal of Environmental Health 42(1):2839

Nas, B. \& Berktay, A. (2006). Groundwater contamination by nitrates in the city of Konya, (Turkey): A GIS perspective. Journal of Environmental Management 79(1):30-37. doi:10.1016/J.Jenvman.2005.05.010

Polat, R.E.A., Şimşek, C. \& Gündüz, O. (2007). İzmir-Nif dağı çevresindek yeraltı suyu nitrat kirliliği boyutunun mevsimsel değerlendirilmesi. 7. Ulusal Çevre Mühendisliği Kongresi (2007), İzmir, Türkiye.

Postma, D., Boesen, C., Kristiansen, H. \& Larsen, F. (1991). Nitrate reduction in an unconfined sandy aquifer - Water chemistry, reduction processes, and geochemical modeling. Water Resources Research 27(8):2027-2045. doi:10.1029/91wr00989

Rathod, H. (2014). Algae based waste water treatment, Indian Institute of Technology Roorkee, Uttarakhand.

Shamrukh, M., Corapcioglu, M.Y. \& Hassona, F.A.A. (2001). Modeling the effect of chemical fertilizers on ground water quality in the Nile Valley aquifer, Egypt. Ground Water 39(1):59-67. doi:10.1111/J.1745-6584.2001.Tb00351.X

Singh, M., Shukla, R. \& Das, K. (2013). Biotechnological applications of microalgae: Biodiesel and value-added products In F. Bux (Ed.), Harvesting of microalgal biomass (pp 77- 87). Boca Raton: CRC Press.

Sönmez, İ.K.M. \& Sönmez, S. (2008). Kimyasal gübrelerin çevre kirliliği üzerine etkileri ve çözüm önerileri. Batı Akdeniz Tarımsal Araştırma Enstitüsü Derim Dergisi 25(2):24-34.

Tesoriero, A.J., Liebscher, H. \& Cox, S.E. (2000). Mechanism and rate of denitrification in an agricultural watershed: Electron and mass balance along groundwater flow paths. Water Resources Research, 36(6):15451559. doi:10.1029/2000wr900035

Tesoriero, A.J. \& Voss, F.D. (1997). Predicting the probability of elevated nitrate concentrations in the Puget Sound Basin: Implications for aquifer susceptibility and vulnerability. Ground Water 35(6):1029-1039. doi:10.1111/J.1745-6584.1997.Tb00175.X

Uğurluoğlu, A. (2013). Seydisuyu Havzası yeraltı su kalitesinin ve kirlilik düzeyinin belirlenmesi. (Yüksek Lisans), Anadolu Üniversitesi.

Upadhyaya, G., Jackson, J., Clancy, T.M., Hyun, S.P., Brown, J. \& Hayes, K. F. (2010). Simultaneous removal of nitrate and arsenic from drinking water sources utilizing a fixed-bed bioreactor system. Water Research 44(17):4958-4969. doi:10.1016/J.Watres.2010.07.037 